\title{
Superoxide dismutase from hen's egg yolk can protect fatty acids from peroxidative damage
}

\author{
Jacek Wawrzykowski • Marta Kankofer
}

Received: 26 April 2014 / Revised: 6 July 2014 / Accepted: 12 July 2014 / Published online: 5 August 2014

(C) The Author(s) 2014. This article is published with open access at Springerlink.com

\begin{abstract}
Superoxide dismutase (SOD, EC1.15.1.1) is a family of enzymes, which remove superoxide anion $\left(\mathrm{O}_{2}^{--}\right)$ from the cells of living organisms. The aim of this study was to describe antioxidative properties of SOD with regard to the protection of unsaturated fatty acids (UFA) from peroxidative damage and to compare this effect with butylated hydroxytoluene (BHT). In this experiment, $\mathrm{Cu}, \mathrm{Zn}-\mathrm{SOD}$ from hen's egg yolk with a mass of $15.59 \pm 0.38 \mathrm{kDa}$ and pI $6.58 \pm 0.10,6.41 \pm 0.08$ and $6.30 \pm 0.15$ was used to protect fatty acids from peroxidative damage in vegetable oil (sunflower oil and olive oil) during 200 days of storage at different temperatures-4, 20 and $35{ }^{\circ} \mathrm{C}$. Antioxidative properties of SOD and BHT were expressed as the ratio of unsaturated to saturated fatty acids (SFA) in samples after 50, 100 and 200 days of storage as well as the percentage content of selected fatty acids in the examined oils. SOD from egg yolk showed the same or better antioxidant properties with regard to the concentration of linoleic acid (C18:2) contained in sunflower oil and olive oil than the corresponding concentrations of BHT during 200-day storage at 4,20 and $35{ }^{\circ} \mathrm{C}$. The concentration of linoleic acid (C18:2) in the sample with SOD was significantly higher during storage at $35^{\circ} \mathrm{C}$ on day 200 . At all storage temperatures, the ratio of SFA to UFA in samples with the addition of SOD was statistically higher than in oils stored without the antioxidant. With regard to linoleic acid (C18:2), SOD proved to be a better antioxidant than BHT. The results demonstrated better antioxidant properties of SOD from hen's eggs compared with the same concentrations of BHT
\end{abstract}

J. Wawrzykowski $(\bowtie) \cdot$ M. Kankofer

Department of Biochemistry, Faculty of Veterinary Medicine,

University of Life Sciences in Lublin, Akademicka 12,

20-033 Lublin, Poland

e-mail: wawrzykowski@up.lublin.pl at elevated temperatures (at 20 and $35^{\circ} \mathrm{C}$ ) in oil with a high content of UFA. No negative antioxidative effect (worse than that of BHT at a corresponding concentration) of the addition of SOD from egg yolk on fatty acid composition of the tested samples was observed. Though further research is necessary, SOD from hen's egg yolk seems to be a promising natural antioxidant of vegetable oils.

Keywords Vegetable oil · Sunflower oil · Olive oil · Oxidation $\cdot$ Peroxidative damage $\cdot$ SOD $\cdot$ Superoxide dismutase

\section{Introduction}

Lipid oxidation produces not only rancid odors, unpleasant flavors and discoloration, but it can also decrease the nutritional quality and health safety of food due to the degradation of products, resulting in harmful effects on living cells [1]. Vegetable oils with higher contents of unsaturated fatty acids (UFA), especially polyunsaturated fatty acids (PUFA), are more susceptible to oxidation than lipids of animal origin.

In order to overcome the stability problems of oils and fats, synthetic antioxidants, such as butylated hydroxyanisole (BHA), butylated hydroxytoluene (BHT) and tertbutyl hydroquinone (TBHQ), are widely used as food additives in many countries. Recent reports reveal, however, that these compounds may cause many health risks, including cancer and carcinogenesis [2]. That is why the need for natural antioxidants has recently increased because of questions about the long-term safety and negative consumer perception of synthetic antioxidants [3]. Consumers, who are aware of the impact of synthetic additives on the human, expect an increase in the use of natural compounds to replace these synthetic antioxidants. 
In the literature, there are several reports on the use of antioxidants of plant origin, as well as substances of animal origin. Furthermore, some protein hydrolysates from animal and plant sources have also been found to exhibit antioxidant activity [4, 5]. These antioxidants have been investigated mainly with regard to the prevention of lipid oxidation in foods. Shui and Leong [6] found that antioxidants obtained from star fruit (Averrhoa carambola L.) residues slowed the process of rancidity of oil to a greater extent than BHT did.

Egg yolk is widely used as a functional and nutritional ingredient in food products. Egg yolk has been recognized to possess antioxidant properties in a linolenate emulsion [7]. It is reported that egg yolk phospholipids [8] and egg yolk phosvitin $[9,10]$ have antioxidant effects. Some studies on the use of protein hydrolysates of lecithin-free egg yolk as an antioxidant [11] have been performed. The results from Sakanaka et al. [12] suggest that egg yolk protein hydrolysates could be a suitable natural antioxidant for preventing the oxidation of PUFA and related food ingredients.

Superoxide dismutases (SOD, EC 1.15.1.1) are a family of important antioxidant metallo-enzymes involved in scavenging the high level of reactive oxygen species (ROS) into molecular oxygen and hydrogen peroxide via the dismutation of superoxide. Depending on the ions in the active site, three main metal ion forms are found in living organisms [13-16]. The dimeric, cytosolic $\mathrm{Cu}, \mathrm{Zn}$-SOD share a large structural similarity of the two monomers, such as a conserved tertiary structure and arrangement, as well as an almost identical total number of inter- and intramolecular hydrogen bonds and salt bridges. There are some reports of the preparation of SOD extracts from various sources among others, bacteria, algae, plants, insects, fish and animal tissue [17-21]. However, commercially available preparations are SODs derived from the plasma of animals, mainly cattle. Due to the occurrence of cases of prion disease of cattle as well as foot and mouth disease in cattle, these products seem unattractive. The European Commission has excluded from the definition of food additives products obtained from the plasma of animals [22]. This opens new possibilities to search for other cheap and secure sources of SOD, which can be used as a food additive.

Roginsky and Barsukova [23] showed that the addition of SOD from bovine erythrocytes inhibits the process of lipid oxidation. The specific inhibiting effect of SOD during PUFA oxidation means that $\mathrm{O}_{2}^{-}$(most likely in the protonated form as $\mathrm{HO}_{2}$ ) participates in radical chain propagation. The proposed mechanism of formation of superoxide and hydroxyl radicals during the oxidation of PUFA is shown in Eq. 1.

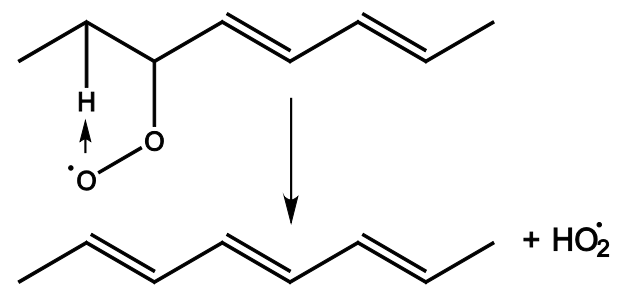

Benson [24] described that the process of forming a radical $\left(\mathrm{LO}_{2}\right)$ of PUFA is thermodynamically easier than the formation of saturated fatty acids (SFA) or mono-unsaturated ones (MUFA). However, even a profound purge of the system from $\mathrm{O}_{2}^{-}\left(\mathrm{HO}_{2}\right)$ does not completely terminate the radical chain transfer [23].

A hypothesis was proposed that SOD extracted from hen's egg yolk can protect UFA from peroxidative damage and prevent the rancidity of food lipids.

The objective of this study was to examine the effect of the $\mathrm{Cu}, \mathrm{Zn}$-SOD extracted from hen's egg yolk on the composition of olive and sunflower oil during storage for 200 days at different temperatures and to compare it with the commonly used synthetic antioxidant BHT.

\section{Materials and methods}

Preparation of enzymatic protein

Ten grams of hen's egg yolk was mixed with $10 \mathrm{~mL}$ of $0.9 \% \mathrm{NaCl}$ and $50 \mathrm{~mL}$ of chloroform:ethanol mixture (5:3), vortexed shortly and centrifuged at $3,000 \times \mathrm{g}$ at $4{ }^{\circ} \mathrm{C}$. Supernatant was collected and evaporated in laboratory evaporator to $50 \mathrm{~mL}$ volume. Protein content in supernatant was determined in triplicate using spectrophotometric biuret method [25]. Enzymatic protein was subjected to 2D electrophoresis and Western blotting in order to confirm the presence of SOD in obtained material.

The activity of SOD in egg white was analyzed previously [31] and appeared to be very low, at the level of error of the method. It was the reason why egg white was not considered as the potent source of enzyme in the present study.

Isoelectric focusing was performed loading $10 \mu \mathrm{g}$ proteins by in-gel rehydration in a volume of $125 \mu \mathrm{L}$ denaturating the 2D buffer ( $8 \mathrm{M}$ urea, $4 \%$ CHAPS, $70 \mathrm{mM}$ DTT, $0.5 \%$ Ampholyte $\mathrm{pH} 4-7$ ) onto $7 \mathrm{~cm}$ IPG Ready Strip linear $\mathrm{pH}$ 3-10 (Bio-Rad, Warsaw, Poland) and focused for $30 \mathrm{kVh}$, using a PROTEAN ${ }^{\circledR}$ IEF system (Bio-Rad, Warsaw, Poland). Before loading onto SDS-polyacrylamide gels, IPG strips were incubated for $10 \mathrm{~min}$ in equilibration buffer (50 mM Tris-HCl, pH 8.8, $6 \mathrm{M}$ urea, $30 \%$ glycerol, $2 \%$ SDS) containing $1 \%$ DTT and then for another $5 \mathrm{~min}$ in equilibration buffer containing $2.5 \%$ iodoacetamide. 
The SDS-polyacrylamide gels $15 \%$ were cast according to Laemmli [26]. The second dimension was performed using a Hoefer SE600 (GE Healthcare Life Sciences, Warsaw, Poland). Silver nitrate staining of gels was performed according to Shevchenko et al. [27].

After 2D-PAGE, proteins were transferred to ImmunBlot PVDF (polyvinylidene difluoride; Bio-Rad, Warszawa, Poland) in accordance with the procedure described by Towbin et al. [28] lasting $2 \mathrm{~h}$ at $100 \mathrm{~V}$ and $4{ }^{\circ} \mathrm{C}$. Specific immune reactions were performed with sheep antibovine $\mathrm{Cu}, \mathrm{Zn}$-SOD antibodies (AbDSerotec, Oxford, UK) at a working concentration of $1 \mu \mathrm{g} / \mathrm{mL}$ for $12 \mathrm{~h}$ at $4{ }^{\circ} \mathrm{C}$. The visualization of immune reactions was prepared in accordance with Blake et al. [29] with secondary polyclonal donkey antibody directed against sheep IgG conjugated with alkaline phosphatase (Abcam, Cambridge, MA, USA) at a concentration of $0.25 \mu \mathrm{g} / \mathrm{mL}$.

Images of the silver-stained gel and membranes were digitized using an Image Scanner III (GE Healthcare Life Sciences, Warsaw, Poland).

\section{Enzyme assay}

SOD activity was determined using a modified epinephrine assay [30]. The method was adapted and optimized to conditions in eggs [31]. Changes in the absorbance were recorded on Ultrospec 2000 spectrophotometer (Pharmacia, Uppsala, Sweden).

The one unit of SOD (U SOD) activity was equivalent to the quantity of SOD that caused a $50 \%$ inhibition of the autooxidation of epinephrine. The SOD activity was expressed as the value of U SOD per $g$ of extracted protein (U SOD.g ${ }^{-1}$ ).

\section{FAME determination}

Samples of olive oil and sunflower oil (from a local market) were mixed with $\mathrm{Cu}, \mathrm{Zn}$-SOD extracted from hen's egg yolk or BHT (Sigma-Aldrich, Poznań, Poland) at final concentrations of $0,0.02,0.04$ and $0.06 \%$, respectively. Samples were stored in the dark at temperatures of 4, 20 and $35{ }^{\circ} \mathrm{C}$ for 200 days. Analyses of fatty acid profile were performed at day 1, 50, 100 and 200 of storage.

Samples of oil were saponified with $\mathrm{KOH}$, and the fatty acids esterified (with $10 \%$ solution of $\mathrm{BF}_{3}$ in methanol) in accordance with AOAC methods [32, 33].

The samples were analyzed on a Varian 3800 GC (Varian, Candela, Warsaw, Poland) using 105 m Rtx-2330 column with I.D. $0.25 \mathrm{~mm}$ and $0.25 \mu \mathrm{m}$ film thickness (Restek, Bellefonte, PA, USA) with $1 \mathrm{~mL} / \mathrm{min}$ helium constant flow, injection temperature of $250^{\circ} \mathrm{C}$, split ratio of $20: 1$ and temperature range from 60 to $250{ }^{\circ} \mathrm{C}$ at $5 \%$ min.

The percentage of the content of the following fatty acids in examined oils was determined: myristic acid (C14:0), palmitic acid (C16:0), palmitoleic acid (C16:1), ginkgolic acid (C17:1), stearic acid (C18:0), oleic acid (C18:1), linoleic acid (C18:2), $\alpha$-linolenic acid and $\gamma$-linolenic acid (the sum of the results represented linoleic acid isomers, C18:3), arachidic acid (C20:0), gondoic acid (C20:1) and tricosylic acid (C23:0).

The ratio of the total content of unsaturated fatty acids to total saturated fatty acid $\left(\mathrm{R}_{\mathrm{UFA} / \mathrm{SFA}}\right)$ was calculated according to Eq. 2.

$\mathrm{R}_{\mathrm{UFA} / \mathrm{SFA}}=\frac{\sum[\mathrm{C} 18: 1],[\mathrm{C} 18: 2],[\mathrm{C} 18: 3],[\mathrm{C} 20: 1]}{[\mathrm{C} 14: 0][\mathrm{C} 16: 0][\mathrm{C} 18: 0][\mathrm{C} 20: 0][\mathrm{C} 23: 0]}$

Statistical analysis

All of the assays were performed in triplicate. Obtained values were statistically analyzed with SAS 8.0 system (SAS Institute Inc., Cary, NC, USA). A two-way analysis of variance (ANOVA) with $p<0.05$ was used to track the effect of the addition of SOD and BHT as an antioxidant of vegetable oil samples.

\section{Results}

The purity of the enzyme

2D electrophoresis of the enzyme extract obtained from egg yolk confirmed the presence of three isoforms of SOD (MW $15.59 \pm 0.38 \mathrm{kDa}$ and pI $6.58 \pm 0.10,6.41 \pm 0.08$ and $6.30 \pm 0.15$ ) as the main component, which is consistent with reports by Öztürk-Ürek and Tarhan [34]. Western blotting with antibodies directed against bovine erythrocyte SOD allowed to confirm the presence of the expected enzyme protein (Fig. 1). This is consistent with the reports of Michalski and Prowse [35] related to the immunological compatibility of $\mathrm{Cu}, \mathrm{Zn}-\mathrm{SOD}$ from bovine and chicken erythrocytes.

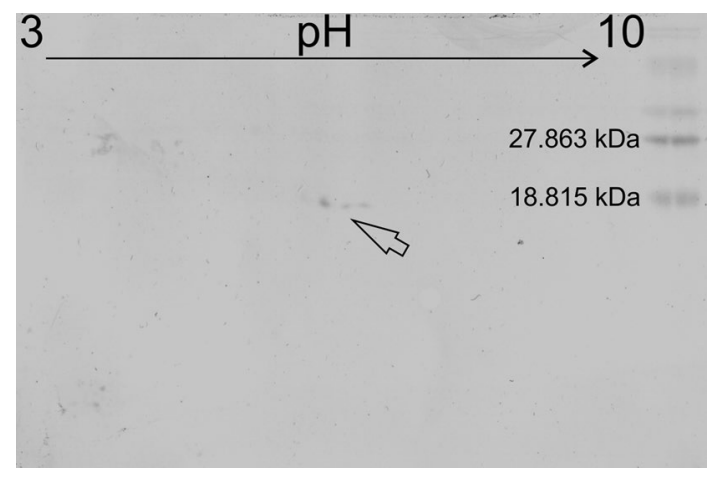

Fig. 1 2D PAGE western blot analysis of $\mathrm{Cu}, \mathrm{Zn}$-SOD from hen egg yolk 
Table 1 Changes in the content of linoleic acid (C18:2) in sunflower oil and olive oil during storage at $4{ }^{\circ} \mathrm{C}$ with the addition of SOD and BHT

Data are reported as mean \pm standard deviation. I, II - various figures indicate statistically significant differences between addition of SOD and BHT (Tukey's test, $p<0.05)$. A, B, C, D-different letters are statistically different linoleic acid content between the timing analysis (Tukey's test, $p<0.05$ ). a, b, c, d, $\mathrm{e}$-different letters indicate significant differences between the content of linoleic acid in the same period, the analysis for different concentrations of additives (Tukey's test, $p<0.05)$

Table 2 Changes in the content of linoleic acid (C18:2) in sunflower oil and olive oil during storage at $20{ }^{\circ} \mathrm{C}$ with the addition of SOD and BHT

Data are reported as mean \pm standard deviation. I, II-various figures indicate statistically significant differences between addition of SOD and BHT (Tukey's test, $p<0.05)$. A, B, C, D-different letters are statistically different linoleic acid content between the timing analysis (Tukey's test, $p<0.05)$. a, b, c, d, $\mathrm{e}$-different letters indicate significant differences between the content of linoleic acid in the same period, the analysis for different concentrations of additives (Tukey's test, $p<0.05)$

\begin{tabular}{|c|c|c|c|c|c|c|}
\hline \multirow[t]{2}{*}{ Oil } & \multirow[t]{2}{*}{ Time } & \multirow[t]{2}{*}{ Addition } & \multicolumn{4}{|c|}{ The concentration of the additive (\%) } \\
\hline & & & 0.00 & 0.02 & 0.04 & 0.06 \\
\hline \multirow[t]{8}{*}{ Sunflower } & 1 & BHT & $60.32 \pm 0.11^{\mathrm{A}}$ & $60.34 \pm 0.05^{\mathrm{II} \mathrm{A} \mathrm{d}}$ & $60.41 \pm 0.10^{\mathrm{II} \mathrm{A} \mathrm{d}}$ & $60.20 \pm 0.16^{\mathrm{II} \mathrm{Ad}}$ \\
\hline & & SOD & & $59.88 \pm 0.58^{\mathrm{IA} \mathrm{bcd}}$ & $60.27 \pm 0.32^{\mathrm{IAd}}$ & $59.89 \pm 0.24^{\mathrm{IA} \mathrm{cd}}$ \\
\hline & 50 & BHT & $59.89 \pm 0.15^{\mathrm{B}}$ & $60.31 \pm 0.16^{\mathrm{II} \mathrm{B} \mathrm{d}}$ & $60.31 \pm 0.13^{\text {II B d }}$ & $60.30 \pm 0.15^{\mathrm{II} \mathrm{B} \mathrm{d}}$ \\
\hline & & SOD & & $60.27 \pm 0.16^{\mathrm{IB} \mathrm{bcd}}$ & $60.13 \pm 0.17^{\mathrm{IB} \mathrm{d}}$ & $60.18 \pm 0.11^{\mathrm{IBcd}}$ \\
\hline & 100 & BHT & $59.75 \pm 0.51^{\mathrm{C}}$ & $60.10 \pm 0.08^{\mathrm{IICd}}$ & $60.07 \pm 0.20^{\amalg \mathrm{Cd}}$ & $60.15 \pm 0.14^{\mathrm{IIC} \mathrm{d}}$ \\
\hline & & SOD & & $59.49 \pm 0.19^{\mathrm{IC} \mathrm{bcd}}$ & $59.92 \pm 0.48^{\mathrm{IC} \mathrm{d}}$ & $59.76 \pm 0.20^{\mathrm{IC} \mathrm{cd}}$ \\
\hline & 200 & BHT & $59.30 \pm 0.45^{\mathrm{D}}$ & $59.94 \pm 0.05^{\mathrm{II} \mathrm{Dd}}$ & $59.87 \pm 0.11^{\mathrm{II} \mathrm{D} \mathrm{d}}$ & $59.90 \pm 0.08^{\mathrm{II} \mathrm{D} \mathrm{d}}$ \\
\hline & & SOD & & $59.76 \pm 0.15^{\mathrm{ID} \mathrm{bcd}}$ & $59.82 \pm 0.06^{\mathrm{IDd}}$ & $59.88 \pm 0.08^{\mathrm{I} \mathrm{D} \mathrm{cd}}$ \\
\hline \multirow[t]{8}{*}{ Olive } & 1 & BHT & $5.21 \pm 0.16^{\mathrm{A}}$ & $5.04 \pm 0.01^{\mathrm{IA} \mathrm{a}}$ & $5.21 \pm 0.07^{\mathrm{IA} \mathrm{a}}$ & $5.27 \pm 0.43^{\mathrm{IA} \mathrm{ab}}$ \\
\hline & & SOD & & $4.92 \pm 0.08^{\mathrm{IA} \mathrm{ab}}$ & $5.09 \pm 0.14^{\mathrm{IA} \mathrm{ab}}$ & $4.94 \pm 0.08^{\mathrm{IA} \mathrm{ab}}$ \\
\hline & 50 & BHT & $5.06 \pm 0.02^{\mathrm{B}}$ & $5.05 \pm 0.01^{\mathrm{IAB} \mathrm{a}}$ & $5.04 \pm 0.01^{\mathrm{IAB} a}$ & $5.06 \pm 0.00^{\mathrm{IAB} \text { ab }}$ \\
\hline & & SOD & & $5.05 \pm 0.03^{\mathrm{IAB} \mathrm{ab}}$ & $5.04 \pm 0.00^{\mathrm{IAB} a b}$ & $5.02 \pm 0.02^{\mathrm{I} A B \text { ab }}$ \\
\hline & 100 & BHT & $5.02 \pm 0.16^{\mathrm{B}}$ & $4.93 \pm 0.05^{\mathrm{IB} \mathrm{a}}$ & $4.93 \pm 0.04^{\mathrm{IB} \mathrm{a}}$ & $5.28 \pm 0.38^{\mathrm{IB} \mathrm{ab}}$ \\
\hline & & SOD & & $4.96 \pm 0.05^{\mathrm{I} \mathrm{AB} \mathrm{ab}}$ & $5.10 \pm 0.02^{\mathrm{I} \mathrm{AB} \mathrm{ab}}$ & $5.11 \pm 0.07^{\mathrm{IAB} \text { ab }}$ \\
\hline & 200 & BHT & $4.93 \pm 0.04^{\mathrm{C}}$ & $5.04 \pm 0.01^{\mathrm{IB} \mathrm{a}}$ & $4.98 \pm 0.11^{\mathrm{IB} \mathrm{a}}$ & $5.01 \pm 0.09^{\mathrm{IB} \mathrm{ab}}$ \\
\hline & & SOD & & $5.26 \pm 0.40^{\mathrm{IB} \mathrm{ab}}$ & $5.12 \pm 0.14^{\mathrm{IB} \mathrm{ab}}$ & $5.13 \pm 0.14^{\mathrm{IB} \mathrm{ab}}$ \\
\hline
\end{tabular}

\begin{tabular}{|c|c|c|c|c|c|c|}
\hline \multirow[t]{2}{*}{ Oil } & \multirow[t]{2}{*}{ Time } & \multirow[t]{2}{*}{ Addition } & \multicolumn{4}{|c|}{ The concentration of the additive $(\%)$} \\
\hline & & & 0.00 & 0.02 & 0.04 & 0.06 \\
\hline \multirow[t]{8}{*}{ Sunflower } & \multirow[t]{2}{*}{1} & BHT & \multirow[t]{2}{*}{$60.32 \pm 0.16^{\mathrm{A}}$} & $60.40 \pm 0.19^{\mathrm{II} \mathrm{A} \mathrm{b}}$ & $60.48 \pm 0.05^{\mathrm{II} \mathrm{A} \mathrm{c}}$ & $60.19 \pm 0.22^{\mathrm{II} \mathrm{A} \mathrm{cd}}$ \\
\hline & & SOD & & $60.33 \pm 0.08^{\mathrm{IA} \mathrm{b}}$ & $60.42 \pm 0.12^{\mathrm{I} \mathrm{A} \mathrm{ab}}$ & $60.16 \pm 0.07^{\mathrm{I} A \mathrm{ab}}$ \\
\hline & \multirow[t]{2}{*}{50} & BHT & \multirow[t]{2}{*}{$59.68 \pm 0.19^{\mathrm{B}}$} & $59.91 \pm 0.18^{\text {II B b }}$ & $59.91 \pm 0.29^{\amalg \mathrm{II}} \mathrm{c}$ & $60.02 \pm 0.22^{\mathrm{II} \mathrm{B} \mathrm{cd}}$ \\
\hline & & SOD & & $59.73 \pm 0.46^{\text {I B b }}$ & $59.96 \pm 0.17^{\mathrm{I} \mathrm{B} \mathrm{ab}}$ & $59.82 \pm 0.44^{\mathrm{IB} a b}$ \\
\hline & \multirow[t]{2}{*}{100} & BHT & \multirow[t]{2}{*}{$57.84 \pm 0.08^{\mathrm{C}}$} & $58.25 \pm 0.22^{\mathrm{II} \mathrm{C} \mathrm{b}}$ & $58.91 \pm 0.42^{\mathrm{II} \mathrm{C} \mathrm{c}}$ & $59.37 \pm 0.17^{\mathrm{II} \mathrm{Ccd}}$ \\
\hline & & SOD & & $58.64 \pm 0.68^{\mathrm{ICb}}$ & $58.29 \pm 0.36^{\mathrm{IC} \mathrm{ab}}$ & $58.53 \pm 0.46^{\mathrm{IC} \mathrm{ab}}$ \\
\hline & \multirow[t]{2}{*}{200} & BHT & \multirow[t]{2}{*}{$55.59 \pm 0.12^{\mathrm{B}}$} & $56.97 \pm 0.12^{\mathrm{II} \mathrm{D} \mathrm{b}}$ & $58.34 \pm 0.12^{\mathrm{II} \mathrm{D} \mathrm{c}}$ & $58.80 \pm 0.10^{\mathrm{II} \mathrm{D} \mathrm{cd}}$ \\
\hline & & SOD & & $56.69 \pm 0.93^{\mathrm{ID} \mathrm{b}}$ & $56.17 \pm 0.60^{\mathrm{ID} \mathrm{ab}}$ & $56.31 \pm 0.58^{\mathrm{ID} \mathrm{ab}}$ \\
\hline \multirow[t]{8}{*}{ Olive } & \multirow[t]{2}{*}{1} & BHT & \multirow[t]{2}{*}{$5.11 \pm 0.04^{\mathrm{A}}$} & $6.36 \pm 1.42^{\mathrm{IA} \mathrm{b}}$ & $5.08 \pm 0.02^{\mathrm{IA} \mathrm{ab}}$ & $5.33 \pm 0.51^{\mathrm{IA} \mathrm{ab}}$ \\
\hline & & SOD & & $5.14 \pm 0.16^{\mathrm{IA} \mathrm{a}}$ & $5.05 \pm 0.02^{\mathrm{IA} \mathrm{ab}}$ & $5.05 \pm 0.03^{\mathrm{IA} \mathrm{ab}}$ \\
\hline & \multirow[t]{2}{*}{50} & BHT & \multirow[t]{2}{*}{$4.94 \pm 0.05^{\mathrm{B}}$} & $4.99 \pm 0.02^{\mathrm{II} \mathrm{AB} \mathrm{b}}$ & $4.97 \pm 0.03^{\mathrm{I} \mathrm{AB} \mathrm{ab}}$ & $5.00 \pm 0.04^{\mathrm{I} A B ~ a b}$ \\
\hline & & SOD & & $4.97 \pm 0.02^{\mathrm{IAB} a}$ & $5.02 \pm 0.04^{\mathrm{I} \mathrm{AB} \mathrm{ab}}$ & $5.00 \pm 0.02^{\mathrm{I} \mathrm{AB} \mathrm{ab}}$ \\
\hline & \multirow[t]{2}{*}{100} & BHT & \multirow[t]{2}{*}{$5.02 \pm 0.01^{\mathrm{C}}$} & $5.07 \pm 0.02^{\mathrm{IB} \mathrm{b}}$ & $5.05 \pm 0.04^{\mathrm{IB} \mathrm{ab}}$ & $5.09 \pm 0.02^{\mathrm{IB} \mathrm{ab}}$ \\
\hline & & SOD & & $5.04 \pm 0.03^{\mathrm{IB} \mathrm{a}}$ & $5.06 \pm 0.03^{\mathrm{IB} \mathrm{ab}}$ & $5.11 \pm 0.04^{\mathrm{IB} \mathrm{ab}}$ \\
\hline & \multirow[t]{2}{*}{200} & BHT & \multirow[t]{2}{*}{$4.97 \pm 0.02^{\mathrm{D}}$} & $5.00 \pm 0.02^{\mathrm{IB} \mathrm{b}}$ & $5.07 \pm 0.06^{\mathrm{IB} \mathrm{ab}}$ & $5.06 \pm 0.01^{\mathrm{IB} \mathrm{ab}}$ \\
\hline & & SOD & & $4.93 \pm 0.11^{\mathrm{IB} \mathrm{a}}$ & $5.03 \pm 0.02^{\mathrm{IB} \mathrm{ab}}$ & $5.04 \pm 0.05^{\mathrm{IB} \mathrm{ab}}$ \\
\hline
\end{tabular}

SOD activity in extracts obtained from egg yolk was $100.2 \pm 9.5 \mathrm{U} \mathrm{SOD} \cdot \mathrm{g}^{-1}$.

The content of linoleic acid

The results of the analysis of linoleic acid (C18:2) during storage of the samples of sunflower oil and olive oil with the addition of SOD and BHT at $4{ }^{\circ} \mathrm{C}$ are shown in Table 1 . A significant difference in the content of linoleic acid has been determined in each period of the analysis. There was no effect of the type and concentration of the additive in the process of peroxidation of linoleic acid at a storage temperature of $4{ }^{\circ} \mathrm{C}$.

The results of the analysis of the content of linoleic acid (C18:2) during storage of the samples of sunflower oil and olive oil with the addition of SOD and BHT at $20^{\circ} \mathrm{C}$ are shown in Table 2. A significant difference in the content of linoleic acid has been detected in each period of analysis. 
Table 3 Changes in the content of linoleic acid (C18:2) in sunflower oil and olive oil during storage at $35{ }^{\circ} \mathrm{C}$ with the addition of SOD and BHT

\begin{tabular}{|c|c|c|c|c|c|c|}
\hline \multirow[t]{2}{*}{ Oil } & \multirow[t]{2}{*}{ Time } & \multirow[t]{2}{*}{ Addition } & \multicolumn{4}{|c|}{ The concentration of the additive (\%) } \\
\hline & & & 0.00 & 0.02 & 0.04 & 0.06 \\
\hline \multirow[t]{8}{*}{ Sunflower } & 1 & BHT & $60.55 \pm 0.40^{\mathrm{A}}$ & $60.46 \pm 0.06^{\mathrm{II} \mathrm{A} \mathrm{bcde}}$ & $60.51 \pm 0.05^{\mathrm{II} \mathrm{A} \mathrm{cde}}$ & $60.49 \pm 0.04^{\mathrm{II} \mathrm{A} \mathrm{e}}$ \\
\hline & & SOD & & $59.88 \pm 0.58^{\mathrm{IA} \mathrm{ab}}$ & $60.27 \pm 0.32^{\mathrm{IA} \mathrm{abc}}$ & $59.89 \pm 0.24^{\text {IA abcde }}$ \\
\hline & 50 & BHT & $59.97 \pm 0.10^{\mathrm{B}}$ & $60.07 \pm 0.11^{\text {II B bcde }}$ & $60.16 \pm 0.16^{\mathrm{II} \mathrm{B} \mathrm{cde}}$ & $60.38 \pm 0.03^{\mathrm{II} \mathrm{B} \mathrm{e}}$ \\
\hline & & SOD & & $60.03 \pm 0.04^{\mathrm{IB} \mathrm{ab}}$ & $60.20 \pm 0.08^{\mathrm{I} \mathrm{B} \mathrm{abc}}$ & $60.29 \pm 0.09^{\mathrm{IB} \text { abcde }}$ \\
\hline & 100 & BHT & $58.91 \pm 0.27^{\mathrm{C}}$ & $59.37 \pm 0.09^{\mathrm{II} \mathrm{C} \text { bcde }}$ & $59.36 \pm 0.08^{\mathrm{II} \mathrm{C} \text { cde }}$ & $59.56 \pm 0.17^{\mathrm{II} \mathrm{Ce}}$ \\
\hline & & SOD & & $58.56 \pm 0.42^{\mathrm{IC} a b}$ & $58.03 \pm 0.31^{\mathrm{IC} a b c}$ & $58.52 \pm 0.23^{\text {I C abcde }}$ \\
\hline & 200 & BHT & $58.50 \pm 0.11^{\mathrm{D}}$ & $59.43 \pm 0.09^{\text {II } \mathrm{D} \text { bcde }}$ & $59.62 \pm 0.13^{\mathrm{II} \mathrm{D} \mathrm{cde}}$ & $59.67 \pm 0.07^{\mathrm{II} \mathrm{D} \mathrm{e}}$ \\
\hline & & SOD & & $58.82 \pm 0.17^{\mathrm{ID} \mathrm{ab}}$ & $59.33 \pm 0.30^{\mathrm{ID} a b c}$ & $60.05 \pm 0.33^{\mathrm{ID} \text { abcde }}$ \\
\hline \multirow[t]{8}{*}{ Olive } & 1 & BHT & $5.12 \pm 0.07^{\mathrm{A}}$ & $5.08 \pm 0.00^{\mathrm{IA} \mathrm{ab}}$ & $5.08 \pm 0.01^{\mathrm{IA} \mathrm{a}}$ & $5.14 \pm 0.08^{\mathrm{I} \mathrm{A} \mathrm{a}}$ \\
\hline & & SOD & & $5.18 \pm 0.19$ & $5.17 \pm 0.20$ & $5.07 \pm 0.01$ \\
\hline & 50 & BHT & $5.04 \pm 0.02^{\mathrm{D}}$ & $5.33 \pm 0.86^{\mathrm{IAB} a b}$ & $5.04 \pm 0.03^{\mathrm{I} \mathrm{AB} \mathrm{a}}$ & $5.05 \pm 0.02^{\mathrm{I} \mathrm{AB} \mathrm{a}}$ \\
\hline & & SOD & & $5.07 \pm 0.01^{\mathrm{IAB} \mathrm{ab}}$ & $5.17 \pm 0.20^{\mathrm{I} A B \mathrm{ab}}$ & $5.18 \pm 0.20^{\mathrm{IAB} a b}$ \\
\hline & 100 & BHT & $5.07 \pm 0.09^{\mathrm{C}}$ & $5.11 \pm 0.02^{\mathrm{IB} \mathrm{ab}}$ & $5.07 \pm 0.15^{\mathrm{IB} \mathrm{a}}$ & $4.98 \pm 0.02^{\mathrm{IB} \mathrm{a}}$ \\
\hline & & SOD & & $5.10 \pm 0.04^{\mathrm{IB} \mathrm{ab}}$ & $5.10 \pm 0.00^{\mathrm{IB} \mathrm{ab}}$ & $5.07 \pm 0.07^{\mathrm{IB} \mathrm{ab}}$ \\
\hline & 200 & BHT & $4.94 \pm 0.08^{\mathrm{D}}$ & $4.92 \pm 0.01^{\mathrm{I} \mathrm{B} \mathrm{a}}$ & $4.94 \pm 0.05^{\mathrm{IB} \mathrm{a}}$ & $4.97 \pm 0.03^{\mathrm{I} \mathrm{B} \mathrm{a}}$ \\
\hline & & SOD & & $5.01 \pm 0.04^{\mathrm{IB} \mathrm{ab}}$ & $5.00 \pm 0.03^{\mathrm{IB} \mathrm{ab}}$ & $5.04 \pm 0.05^{\mathrm{IB} \mathrm{ab}}$ \\
\hline
\end{tabular}

Data are reported as mean \pm standard deviation. I, II-various figures indicate statistically significant differences between addition of SOD and BHT (Tukey's test, $p<0.05$ ). A, B, C, D-different letters are statistically different linoleic acid content between the timing analyses (Tukey's test, $p<0.05)$. a, b, c, d, e-different letters indicate significant differences between the content of linoleic acid in the same period, the analysis for different concentrations of additives (Tukey's test, $p<0.05$ )

With increasing concentration of the additive, an increasing inhibiting effect on the oxidation of linoleic acid was shown. At any time, the addition of SOD inhibited the rate of oxidation at the level similar to BHT.

The results of the analysis of the content of linoleic acid (C18: 2) during storage of the samples of sunflower oil and olive oil with the addition of SOD and BHT at $35{ }^{\circ} \mathrm{C}$ are shown in Table 3. Significant increase in the amount of linoleic acid in the samples preserved by the addition of SOD on the 200th day of storage was noticed.

The analysis of remaining fatty acids indicated similar trends, but it has not been shown.

The ratio of saturated to unsaturated fatty acids

Figure 2 shows the results of the comparisons of the ratio of saturated to unsaturated fatty acids $\left(\mathrm{R}_{\mathrm{UFA} / \mathrm{SFA}}\right)$ in sunflower oil samples stored under different conditions. The results showed no statistical difference between the addition of SOD and BHT in oils stored at $4{ }^{\circ} \mathrm{C}$. At 20 and $35^{\circ} \mathrm{C}$, BHT presented better antioxidant activity. In both temperatures, there was a clear effect of the concentration of BHT in attempts to increase the ratio of saturated to unsaturated fatty acids $\left(\mathrm{R}_{\mathrm{UFA} / \mathrm{SFA}}\right)$. With regard to SOD, there was no impact of the concentration of the additive on the examined ratio.
In any case, the addition of SOD showed positive properties regarding antioxidant protection at a level comparable with BHT.

Figure 3 shows the results of the comparisons of the ratio of saturated to unsaturated fatty acids $\left(\mathrm{R}_{\mathrm{UFA} / \mathrm{SFA}}\right)$ in olive oil samples stored under different conditions. The results showed no statistical difference between the addition of SOD and BHT in oils stored at $4{ }^{\circ} \mathrm{C}$.

At $20{ }^{\circ} \mathrm{C}$, the ratio of saturated to unsaturated fatty acids $\left(\mathrm{R}_{\mathrm{UFA} / \mathrm{SFA}}\right)$ remained statistically higher with the addition of BHT than with the addition of SOD. At $35^{\circ} \mathrm{C}$, there was a clear effect of the addition of SOD in attempts to increase the ratio of saturated to UFA during 200 days of storage. With regard to SOD, there was no impact of the concentration of the additive on the examined ratio.

As in sunflower oil, also in olive oil, the effect of the addition of SOD on the increase of the ratio of saturated to unsaturated fatty acids $\left(\mathrm{R}_{\mathrm{UFA} / \mathrm{SFA}}\right)$ at temperatures of 20 and $35{ }^{\circ} \mathrm{C}$ was detected.

\section{Discussion}

The present study has shown that the addition of SOD to vegetable oils has a positive influence on the content of linoleic acid (18:2) during storage of sunflower oil and olive oil at 20 

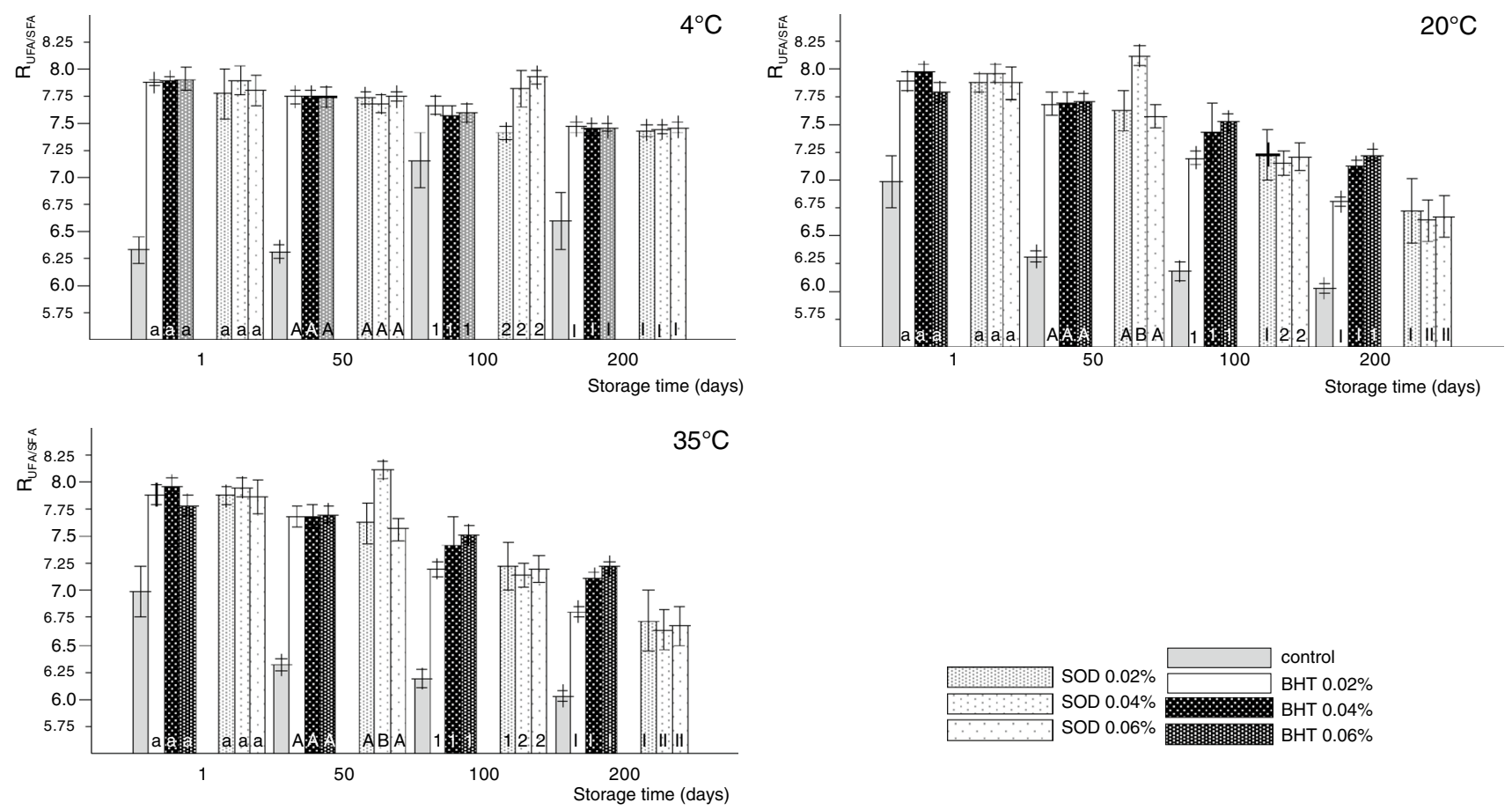

Fig. 2 The ratio of the sum of the percentage of unsaturated fatty acids to saturated fatty acids $\left(\mathrm{R}_{\mathrm{UFA} / \mathrm{SFA}}\right)$ in sunflower oil stored at 4,20 and $35{ }^{\circ} \mathrm{C}$ with BHT and SOD. Data are reported as

mean \pm standard deviation. Different letters indicate significant difference between the components on the same day of analysis (ANOVA with Tukey's test $p<0.05$ )
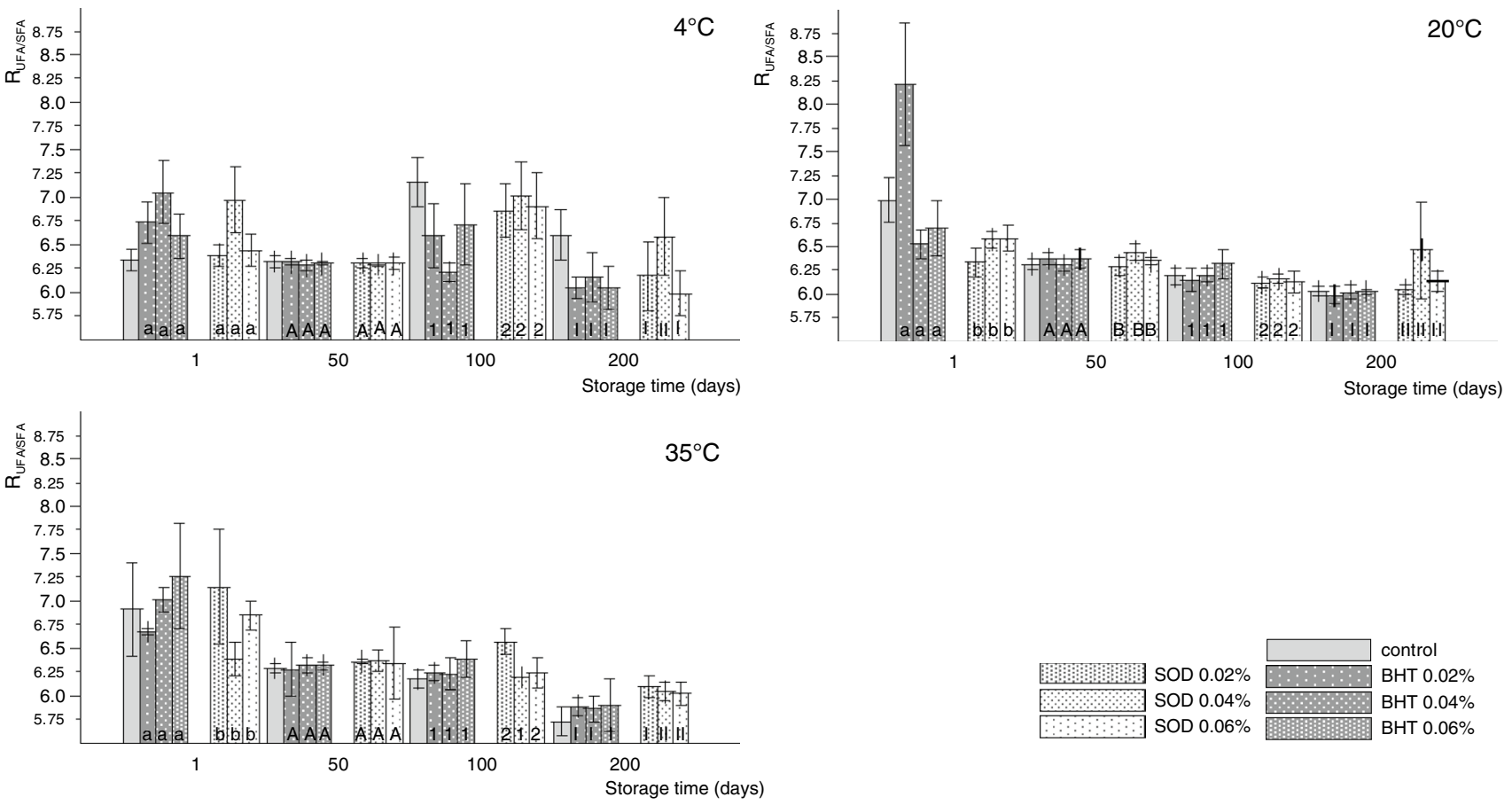

Fig. 3 The ratio of the sum of the percentage of unsaturated fatty acids to saturated fatty acids ( $\left.\mathrm{R}_{\mathrm{UFA} / \mathrm{SFA}}\right)$ in olive oil stored at 4,20 and $35^{\circ} \mathrm{C}$ with BHT and SOD. Data are reported as mean \pm standard deviation. Different letters indicate significant difference between the components on the same day of analysis (ANOVA with Tukey's test $p<0.05)$ 
and $35^{\circ} \mathrm{C}$. During storage of sunflower oil for a period of 200 days, better antioxidant properties of SOD (with regard to the ratio of UFA to SFA) than for similar concentrations of BHT were demonstrated. No effect of SOD concentration on the efficiency of inhibition of the peroxidation of UFA with regard to both sunflower oil and olive oil was also detected. Such relationship was clearly visible with the addition of BHT. During the storage of oil samples for 200 days at different temperatures, SOD showed similar properties in the prevention of fatty acid oxidative damage as BHT.

Worldwide vegetable oil consumption is expected to grow by $2 \%$ per year as a result of increasing edible oil and renewable energy demands [36] and that is why appropriate protection of fatty acids is of vital importance. A striking feature of sunflower oil was the relative high level of PUFA and MUFA. From the health point of view, MUFA have been shown to lower "bad" LDL cholesterol (low density lipoproteins) and retain "good" HDL cholesterol (high density lipoproteins). This is in fact the major benefit of olive oil over the highly polyunsaturated seed oils, wherein PUFA reduce both the "bad" as well as the "good" serum cholesterol levels in our blood [37].

Oxidative reactions limit the half-life of fresh and processed foodstuff and are of serious concern in food industry. ROS easily attack multiple bonds in UFA, lead to a number of subsequent reactions which result in changes in the quantitative composition of the fat, and produce others compounds which can be dangerous to the consumer [38]. That is why antioxidants are often added to food to prevent the radical chain reactions and they act by inhibiting the initiation and propagation steps, consequently delaying the oxidation process.

BHT is a synthetic phenolic antioxidant widely used as a food additive. It is very effective in the protection of unsaturated oils and is therefore used as potential inhibitor of oxidative reaction. It is assumed that the mechanism of its action is based on neutralizing free radicals [39]. However, this results in the formation of potentially dangerous BHT metabolites, mainly 3,5-di-tert-butyl-4-hydroxybenzoic acid and its derivatives which can cause damage in a number of organs such as lung, kidney, liver, and muscle [40, 41]. The use of BHT is limited by law; therefore, it is necessary to search for efficient natural antioxidants without the aforementioned disadvantages [42]. Molecules of protein origin seem to be perfect as antioxidants because they are hydrolyzed in the digestive tract to amino acids, lose their properties and do not exert any harmful effect.

Olive oil and sunflower oil are often used in studies of oxidative changes in fat [43, 44]. Changes in the content of linoleic acid (C18:2) are often monitored as a good indicator of the oxidative degradation of vegetable oils, during long storage or when subjected to elevated temperatures [45].
Sakanaka et al. [12] tested antioxidant properties of the protein hydrolysates of egg yolk. The enzymatically hydrolyzed protein with mass distribution of less than $1 \mathrm{kDa}$ from skimmed egg yolk showed potent antioxidant activity with respect to linoleic acid (C18:2). The effect was dependent on the concentration of the hydrolysate in the sample.

The results of present experiment showed better antioxidant properties of SOD extracted from hen's egg yolk compared with the same concentrations of BHT at elevated temperatures (at 20 and $35^{\circ} \mathrm{C}$ ) in oil with a high content of UFA. Low SOD activity as an antioxidant in the oil stored at $4{ }^{\circ} \mathrm{C}$ can be explained by the low activity of the enzyme protein outside the optimum temperature. In the literature, there is no information available about the optimum temperature for the action of SOD in hens (Gallus gallus domesticus). There are, however, a number of reports describing the optimum temperature for the activity of $\mathrm{Cu}, \mathrm{Zn}-\mathrm{SOD}$ from other species ranging between 25 and $37^{\circ} \mathrm{C}[21,34]$.

Comparing the sunflower oil sample, the relationship between the concentration of BHT and the ratio of the total content of UFA to total SFA content in the analyzed samples was observed. It confirmed the results obtained by Fujisawa et al. [39]. In the case of the addition of SOD, there was no direct link between the concentration of the additive and the ratio of unsaturated to saturated fatty acids in the oil samples, which is consistent with reports by Roginsky and Barsukova [23].

The corresponding results in olive oil similarly showed the effect of the concentration of BHT on the sum of the content of UFA to total saturated fatty acid in the analyzed samples. Such a relationship was not observed with regard to the addition of SOD from chicken eggs.

Our results confirm the statement that SOD is a second type (secondary) hen's egg oxidant, which does not directly interrupt the free radical chain reaction, but acts on the intermediate products and is not consumed during the reaction $[23,46]$.

\section{Conclusions}

SOD isolated from hen's egg yolk can protect fatty acids from peroxidative damage and prevent the process of rancidity in food lipids in a similar or even better way than BHT.

\section{Conflict of interest None.}

Compliance with Ethics Requirements The study was approved by the local ethics committee (II Local Ethical Committee for Experiments on Animals at the University of Life Sciences in Lublin, resolution no. 1/2012 dated January 17, 2012). 
Open Access This article is distributed under the terms of the Creative Commons Attribution License which permits any use, distribution, and reproduction in any medium, provided the original author(s) and the source are credited.

\section{References}

1. Lercker G, Rodriguez-Estrada MT (2002) In: Guardiola F, Dutta PC, Codony R, Savage GP (eds) Cholesterol and phytosterol oxidation products: analysis, occurrence and biological effects. AOCS Press, Champaign

2. Prior RL (2004) In: Meskin M, Bidlack WR, Davies AJ, Lewis DS, Randolph RK (eds) Phytochemicals: mechanisms of action. CRC Press, Boca Raton

3. Yu L, Haley S, Perret J, Harris M, Wilson J, Qian M (2002) Free radical scavenging properties of wheat extracts. J Agric Food Chem 50:619-1624

4. Amarowicz R, Shahidi F (1997) Antioxidant activity of peptide fraction of capelin protein hydrolysates. Food Chem 58:355-359

5. Pena-Ramos EA, Xiong YL (2002) Antioxidant activity of soy protein hydrolysates in a liposomal system. J Food Sci 67:2952-2956

6. Shui G, Leong LP (2006) Residue from star fruit as valuable source for functional food ingredients and antioxidant nutraceuticals. Food Chem 97:277-284

7. Yamamoto Y, Sogo N, Iwao R, Miyamoto T (1990) Antioxidant effect of egg yolk on linoleate in emulsion. Agric Biol Chem 54:3099-3104

8. King MF, Boyd LC, Sheldon BW (1992) Antioxidant properties of individual phospholipids in a salmon oil model system. J Am Oil Chem Soc 69:545-551

9. Lu CL, Baker RC (1987) Effect of pH and food ingredients on the stability of egg yolk phospholipids and the metal-chelator antioxidant activity of phosvitin. J Food Sci 52:613-616

10. Lee SK, Han JH, Decker EA (2002) Antioxidant activity of phosvitin in phosphatidylcholine liposomes and meat model systems. J Food Sci 67:37-41

11. Park PJ, Jung WK, Nam KS, Shahidi F, Kim SK (2001) Purification and characterization of antioxidative peptides from protein hydrolysates of lecithin-free egg yolk. J Am Oil Chem Soc 78:651-656

12. Sakanaka S, Tachibana Y, Ishihara N, Juneja LR (2004) Antioxidant activity of egg-yolk protein hydrolysates in a linoleic acid oxidation system. Food Chem 86:99-103

13. Schininà ME, Carlini P, Polticelli F, Zappacosta F, Bossa F, Calabrese $\mathrm{L}$ (1996) Amino acid sequence of chicken $\mathrm{Cu}, \mathrm{Zn}$-containing superoxide dismutase and identification of glutathionyl adducts at exposed cysteine residues. Eur J Biochem 237:433-439

14. Alscher RG, Erturk N, Heath LS (2002) Role of superoxide dismutases (SODs) in controlling oxidative stress in plants. J Exp Bot 53:1331-1341

15. Due AV, Petersen SV, Valnickova Z, Østergaard L, Oury TD, Crapo JD, Enghild JJ (2006) Extracellular superoxide dismutase exists as an octamer. FEBS Lett 580:1485-1489

16. Vanaporn M, Wand M, Michell SL, Sarkar-Tyson M, Ireland P, Goldman S, Kewcharoenwong C, Rinchai D, Lertmemongkolchai G, Titball RW (2011) Superoxide dismutase C is required for intracellular survival and virulence of Burkholderia pseudomallei. Microbiology 157:2392-2400

17. Mista HP, Keele BB (1975) The purification and properties of superoxide dismutase from a blue-green alga. Biochim Biophys Acta 379:418-425

18. Benov LT, Beyer WF Jr, Stevens RD (1996) Purification and characterization of $\mathrm{Cu}, \mathrm{Zn}$-SOD from Escherichia coli. Free Radic Biol Med 21:117-121
19. Ookawara O, Kizaki T, Oh-ishi S, Yamamoto M (1997) Purification and subunit structure of extracellular superoxide dismutase from mouse lung tissue. Arch Biochem Biophys 340:299-304

20. Osatomi K, Masuda Y, Hara K, Ishihara T (2001) Purification, $\mathrm{N}$-terminal aminoacid sequence, and some properties of $\mathrm{Cu}, \mathrm{Zn}$ superoxide dismutase from Japanese flounder (Paralichthys olivaceus) hepato-pancreas. Comp Biochem Physiol B Comp Biochem 128:751-760

21. Vyas D, Kumar S (2005) Purification and partial characterization of a low temperature responsive Mn-SOD from tea (Camellia sinensis (L.) O. Kuntze). Biochem Biophys Res Commun 329:831-838

22. Regulation of the European parliament and of the council on food additives, Commission of the European Communities, Brussels, 28.7.2006, COM (2006) 428. http://eur-lex.europa.eu. Accessed 28 Sept 2006

23. Roginsky V, Barsukova T (2001) Superoxide dismutase inhibits lipid peroxidation in micelles. Chem Phys Lipids 111:87-91

24. Benson SW (1968) Thermochemical kinetics. Wiley, London

25. Gornal AG, Bardawill CJ, David MM (1949) Determination of serum proteins by means of the biuret method reaction. J Biol Chem 177:751-766

26. Laemmli UK (1970) Cleavage of structural proteins during the assembly of the head of bacteriophage T4. Nature 227:680-685

27. Shevchenko A, Wilm M, Vorm O, Mann M (1996) Mass spectrometric sequencing of proteins silver-stained polyacrylamide gels. Anal Chem 68:850-858

28. Towbin H, Staechelin T, Gordon J (1979) Electrophoretic transfer of proteins from polyacrylamide gels to nitrocellulose sheets: procedure and some applications. Proc Natl Acad Sci USA $76: 4350-4354$

29. Blake MS, Johnston KH, Russell-Jones GJ, Gotschlich EC (1984) A rapid, sensitive method for detection of alkaline phosphatase-conjugated anti-antibody on Western blots. Anal Biochem 136:175-179

30. Sun M, Zigman S (1978) Determination of superoxide dismutase in erythrocytes using the method of adrenalin autooxidation. Anal Biochem 90:81-89

31. Wawrzykowski J, Kankofer M (2011) Changes in activity during storage and characteristics of superoxide dismutase from hen eggs (Gallus gallus domesticus). Eur Food Res Technol 232:479-484

32. AOAC method 963.22 (2000) Methyl Esters of Fatty Acids in Oils and Fats. Official Methods of Analysis of the AOAC, 17th edn. AOAC, Arlington

33. AOAC method 969.33. (2000) Fatty Acids in Oils and Fats. Official Methods of Analysis of the AOAC, 17th edn. AOAC, Arlington

34. Öztürk-Ürek R, Tarhan L (2001) Purification and characterization of superoxide dismutase from chicken liver. Comp Biochem Physiol B Comp Biochem 128:205-212

35. Michalski WP, Prowse SJ (1991) $\mathrm{Cu}, \mathrm{Zn}$ superoxide dismutase from chicken erythrocytes. Comp Biochem Physiol B Comp Biochem 100:371-375

36. Food and Agriculture Organization of the United Nations. (2012) OECD-FAO Agricultural Outlook 2013. Doi:10.1787/agr_outlook-2013-en

37. Hassanien MFR, Kinni SG, Mörsel JT (2012) Bioactive lipids, fatty acids and radical scavenging activity of Indian Celastrus paniculatus oil. J Appl Bot Food Qual 83:57-162

38. Kobayashi H, Yoshida M, Miyashita K (2003) Comparative study of the product components of lipid oxidation in aqueous and organic systems. Chem Phys Lipids 126:111-120

39. Fujisawa S, Kadoma Y, Yokoe I (2004) Radical-scavenging activity of butylated hydroxytoluene (BHT) and its metabolites. Chem Phys Lipids 130:189-195 
40. Matsuo M, Mihara K, Okuno M, Ohkawa H, Miyamoto J (1984) Comparative metabolism of 3,5-di-tert-butyl-4 hydroxytoluene (BHT) in mice and rat. Food Chem Toxicol 22:345-354

41. Yamamoto K, Tajima K, Takeyama M, Mizutani T (1991) Further metabolism of 3,5-di-tert-butyl-4-hydroxybenzoic acid, a major metabolite of butylated hydroxytoluene in rats. Chem Pharm Bull (Tokyo) 39:512-514

42. Babich H (1982) Butylated hydroxytoluene (BHT): a review. Environ Res Lett 29:1-29

43. Muik B, Lendl B, Molina-Díaz A, Ayora-Cañada MJ (2005) Direct monitoring of lipid oxidation in edible oils by Fourier transform Raman spectroscopy. Chem Phys Lipids 134:173-182
44. Smith SA, King RE, Min DB (2007) Oxidative and thermal stabilities of genetically modified high oleic sunflower oil. Food Chem 102:1208-1213

45. Marinova EM, Seizova KA, Totseva IR, Panayotova SS, Marekov IN, Momchilova SM (2012) Oxidative changes in some vegetable oils during heating at frying temperature. Bulg Chem Commun 44:57-63

46. Reische DW, Lillard DA, Eitenmiller RR (2002) In: Akoh CC, Min DB (eds) Food lipids, 2nd edn. CRC Press, New York 